\title{
UPAYA PENINGKATAN KEMAMPUAN GURU DALAM MEMPERSIAPKAN RPP DI TK AL MUSTAFA KOTA JAMBI
}

\author{
NIRWANA \\ TK Kembar Lestari Jambi \\ Email: nirwanajambi397@gmail.com
}

\begin{abstract}
ABSTRAK
Penelitian ini menggunakan jenis penelitian tindakan Sekolah (PTS). Dalam pelaksanaannya penelitian ini terbagi atas 2 siklus yaitu siklus I, dan siklus II. Berdasarkan hasil penelitian tindakan sekolah (PTS) dapat disimpulkan sebagai berikut: In house training mampu meningkatkan kompetensi guru TK Al Mustafa Kota Jambi dalam menyusun Rencana Pelaksanaan Pembelajaran (RPP). Hal itu dapat dibuktikan dari hasil observasi yang memperlihatkan bahwa terjadi peningkatan kompetensi guru dalam menyusun Rencana Pelaksanaan Pembelajaran (RPP) dari siklus ke siklus. Pada siklus I nilai rata-rata komponen Rencana Pelaksanaan Pembelajaran (RPP) $74 \%$ dan pada siklus II $86 \%$. Jadi, terjadi peningkatan $12 \%$ dari siklus I.

Pendampingan yang dilakukan pengawas dengan melakukan kegiatan in House Trainng terhadap guru mampu meningkatkan kompetensi guru dalam menyusun rencana pelaksanaan pembelajaran (RPP). Jadi, pengawas dan kepala sekolah perlu secara kontinu melakukan pendampingan dan pembinaan kepada guru agar kemampuan guru dapat terusmeningkat.
\end{abstract}

\section{Kata Kunci: Kompetensi guru, Guru, RPP}

\section{A. PENDAHULUAN}

\section{Latar Belakang}

Rencana Pelaksanaan Pembelajaran (RPP) adalah rencana yang menggambarkan prosedur, dan pengorganisasian pembelajaran untuk mencapai satu kompetensi dasar yang ditetapkan. Dalam standar isi yang telah dijabarkan dalam silabus. Ruang lingkup rencana pembelajaran paling luass mencakup 1 (satu) kompetensi dasar yang terdiri atas 1(satu) atau beberapa indikator untuk 1 (satu) kali pertemuan atau lebih.

Secara definisi rencana pelaksanaan pembelajaran merupakan keseluruhan proses pemikiran dan penentuan semua aktivitas yang akan dilakukan pada masa kini dan masa yang akan datang dalam rangka mencapai tujuan. Menurut Peraturan Pemerintah (PP) No 19 tahun 2005 pasal 20 berbunyi bahwa perencanaan proses pembelajaran meliputi silabus dan rencana pelaksanaan 
pembelajaran yang memuat sekurang-kurangnya tujuan pemebelajaran, materi pembelajaran, metode pembelajaran, sumber belajar dan penilaian hasil belajar.

Masalah penting yang sering dihadapi guru dalam kegiatan pembelajaran adalah menyiapkan Rencana Pelaksanaan Pembelajaran (RPP) yang tepat dalam rangka membantu siswa mencapai kompetensi. Hal ini disebabkan oleh kenyataan bahwa dalam kurikulum atau silabus, Rencana Pelaksanaan Pembelajaran hanya dituliskan secara garis besar dalam bentuk "materi acuan untuk mengajar".

Penyusunan rencana pembelajaran merupakan suatu bagian terpenting dalam melaksanakan proses belajar mengajar di kelas. Dikatakan penting, karena untuk guru Rencana Pelaksanaan Pembelajaran (RPP) tersebut merupakan acuan atau skenario yang harus dilalui tahap demi tahap dalam memberikan materi kepada siswa. Dalam pelaksanaan proses belajar mengajar, setiap guru wajib dan menjadi syarat mutlak untuk membuat Rencana Pelaksanaan Pembelajaran (RPP), sebelum proses penampilan di dalam kelas.

Dalam penyusunan Rencana Pelaksanaan Pembelajaran (RPP), setiap guru harus berpedoman pada program pengajaran setiap bidang studi serta kalender akademik pada saat tahun pelajaran berlangsung. Adapun keuntungan yang diperoleh dari pembuatan Rencana Pelaksanaan Pembelajaran (RPP) adalah sebagai berikut:

1. Guru akan lebih percaya diri dalam menyampaikan materi pembelajaran kepada siswa, karena telah dipersiapkan sebelumnya.

2. Guru dapat menyampaikan materi pembelajaran dengan alur yang telah direncanakan,

3. Guru dapat menggunakan Rencana Pelaksanaan Pembelajaran (RPP) tersebut untuk mengatur durasi penyampaian materi pembelajaran.

Pada kenyataannya ketika guru membuat Rencana Pelaksanaan Pembelajaran (RPP) dengan baik, maka guru tersebut dimudahkan dalam mengajar. namun, yang terjadi di lapangan masih banyak guru yang lamban dalam penyusunan RPP. Hal ini lah yang membuat penulis tertarik untuk membahas lebih lanjut bagaimana meeningkatkan kemampuan guru dalam mempersiapkan Rencana Pelaksanaan Pembelajaran (RPP). 


\section{Rumusan Masalah}

Berdasarkan latar belakang dan pembatasan masalah yang telah diuraikan di atas, maka masalah pokok dalam penelitian ini dapat dirumuskan sebagai berikut:

a. Bagaimanakah kemampuan guru dalam menyusun Rencana Pelaksanaan Pembelajaran (RPP) dalam mempersiapkan proses belajar mengajar ?

b. Bagaimanakah upaya guru dalam meningkatkan penyusunan Rencana Pelaksanaan Pembelajaran (RPP) melalui bimbingan secara intensif?

\section{Tujuan Penelitian}

Tujuan penelitian tindakan sekolah ini adalah untuk:

1. Mengetahui kemampuan guru dalam menyusun (RPP) dalam mepersiapkan proses belajar mengajar

2. Mengetahui upaya guru dalam meningkatkan penyusunan Rencana Pelaksanaan Pembelajaran (RPP) melalui bimbingan secara intensif.

\section{Manfaat Penelitian}

- Bagi Kepala sekolah:

a. Peningkatkan kemampuan kepala Sekolah tentang lingkup kerjanya.

b. Peningkatan profesionalisme kepala sekolah dalam pembinaan terhadap guru.

\section{- Bagi Guru:}

a. Terjadinya perbaikan dan peningkatan mutu proses pembelajaran dan hasil belajar.

b. Guru akan lebih professional dalam memfasilitasi siswa belajar sehingga proses belajar semakin bermakna.

c. Guru mampu menciptakan iklim belajar yang menyenangkan.

\section{- Bagi Siswa:}

a. Siswa semakin bersemangat belajar sehingga pemahaman konsep lebih mudah diterima.

b. Interaksi pembelajaran semakin lancar dan hasil belajar meningkat, dan KKM dapat dicapai.

c. Aktivitas dan kreativitas serta inovasi pelajar meningkat. 


\section{B. TINJAUAN PUSTAKA}

\section{Kompetensi Guru}

Di dalam Undang-Undang Republik Indonesia Nomor 14 Tahun 2005 tentang Guru dan Dosen, dijelaskan bahwa kompetensi adalah seperangkat pengetahuan, keterampilan, dan perilaku yang harus dimiliki, dihayati, dan dikuasai oleh guru atau dosen dalam melaksanakan tugas keprofesionalan.

Di dalam pasal 10 ayat (1) UU guru dan dosen No. 14 tahun 2005 dinyatakan bahwa kompetensi guru meliputi kompetensi paedagogik, kompetensi kepribadian, kompetensi sosial, dan kompetensi profesonal yang diperoleh melalui pendidikan profesi. ${ }^{1}$

Pengertian kompetensi guru adalah seperangkat penguasaan kemampuan yang harus ada dalam diri guru agar dapat mewujudkan kinerjanya secara tepat dan efektif. Kompetensi guru merupakan perpaduan antara kemampuan personal, keilmuan, teknologi, sosial, dan spiritual yang secara kaffah membentuk kompetensi standar profesi guru, yang mencangkup penguasaan materi, pemahaman terhadap peserta didik, pembelajaran yang mendidik, pengembangan pribadi dan profesioanalisme. $^{2}$

Kompetensi guru merupakan perpaduan antara kemampuan personal, keilmuan, teknologi, social, dan spiritual yang secara kaffah membentuk kompetensi standar profesi guru, yang mencakup penguasaan materi, pemahaman terhadap peserta didik, pembelajaran yang mendidik, pengembangan pribadi, dan profesionalisme.7

\section{Rencana Pelaksanaan Pembelajaran (RPP)}

Beberapa pengertian tentang perencanaan pembelajaran antara lain: ${ }^{3}$

a. Proses mempersiapkan kegiatan-kegiatan secara sistematis yang akan dilakukan untuk mencapai suatu tujuan tertentu.

\footnotetext{
${ }^{1}$ UU RI No. 14 Th. 2005, Guru dan Dosen, (Jakarta: Sinar Grafika, 2006), hal. 7.

${ }^{2}$ Kunandar, Guru Profesional Implementasi KTSP dan Persiapan Menghadapi Sertifikasi Guru, (Jakarta: Rajagrafindo Persada, 2007), hal. 55.

${ }^{3}$ E. Mulyasa, Kurikulum Tingkat Satuan Pendidikan, (Bandung: PT. Remaja Rosdakarya, 2007), Cet Ke-4, h. 216.
} 
b. Perhitungan dan penentuan tentang sesuatu yang akan dijalankan dalam rangka mencapai tujuan tertentu. Siapa yang melakukan? Kapan? Dimana? Bagaimana cara melakukannya?

c. Sebagai keseluruhan proses pemikiran dan penentuan secara matang menyangkut hal-hal yang akan dikerjakan di masa akan datang dalam rangka mencapai tujuan yang telah ditentukan sebelumnya.

Hal yang sama diungkapkan oleh E. Mulyasa, Rencana Pelaksanaan Pembelajaran (RPP) pada hakekatnya merupakan perencanaan jangka pendek untuk memperkirakan atau memproyeksikan apa yang akan dilakukan dalam pembelajaran.

Dari beberapa pengertian perencanaan yang dikemukakan oleh para pakar, tetapi pada dasarnya perencanaan memiliki kata kunci "penentuan aktivitas yang akan dilakukan" kata kunci ini mengidentifikasikan bahwa perencanaan merupakan kegiatan untuk menentukan masa yang akan datang. Karena pekerjaan yang ditentukan pada kegiatan perencanaan belum dilaksanakan, maka untuk dapat membuat perencanaan yang baik harus menguasai keadaan yang ada pada saat ini. Dari kondisi yang ada itulah berbagai proyeksi dapat dilakukan dan kemudian dituangkan dalam berbagai rangkaian kegiatan dalam perencanaan dalam hal ini rencana pengajaran di kelas/sekolah.

Beberapa prinsip perencanaan pembelajaran adalah meliputi :

a. Dilakukan oleh sumber daya manusia yang tepat dan kompeten.

Dalam melaksanakan perencanaan pembelajaran maka perencanaan tersebut harus dilakukan oleh orang yang tepat.

b. Memiliki validitas.

Dalam melakukan rencana pembelajaran harus diperhitungkan bagaimana perencanaan tersebut dilaksanakan. Oleh karena itu harus diperhitungkan proses yang akan dilalui untuk dapat mencapai kompetensi yang telah direncanakan tadi.

c. Berpedoman pada masa yang akan datang.

Perencanaan pembelajaran yang dibuat adalah apa yang akan diupayakan untuk dapat dicapai pada kurun waktu yang akan datang. Oleh karena itu apa yang 
akan dicapai dalam perencanaan tersebut adalah sesuatu yang akan dicapai dalam kurun waktu yang akan datang, minimal ketercapaian dari standar minimum yang ditentukan sekolah maupun bidang studi, pada akhir pembelajaran dari suatu bidang/mata pelajaran disetiap semester

\section{METODE PENELITIAN}

\section{Setting Penelitian}

Penelitian tindakan sekolah dilaksanakan di TK Al Mustafa Jln. Lingkar Barat Kota Jambi. Pemilihan sekolah tersebut bertujuan untuk meningkatkan kompetensi guru dalam membuat Rencana Perlaksanaan Pembelajaran (RPP) dengan lengkap.

Subyek dalam Penelitian Tindakan Sekolah (PTS) ini adalah guru TK Al Mustafa Jl. Lingkar Barat Kota Jambi. Subyek penelitian berjumlah enam orang guru kelas.

\section{Teknik dan Alat Pengumpulan Data}

Teknik pengumpulan data dalam penelitian ini adalah wawancara, observasi, dan diskusi. Sedangkan alat pengumpulan data dalam Penelitian Tindakan Kelas (PTS) ini sebagai berikut:

a. Wawancara

Menggunakan panduan wawancara untuk mengetahui kemampuan awal yang dimiliki guru tentang rencana pelaksanaan pembelajaran.

b. Observasi

Menggunakan lembar observasi untuk mengetahui komponen Rencana Pelaksanaan Pembelajaran (RPP yang telah dibuat dan yang belum dibuat oleh guru.

c. Diskusi

Dilakukan dengan maksud untuk sharing pendapat antara peneliti dengan guru 


\section{Validasi Data}

Adapun rumus korelasi yang digunakan adalah diamati dengan tehnik persentasi yang dikemukakan oleh Sudjana yaitu : ${ }^{4}$

$$
\begin{aligned}
& \mathrm{P}=\quad \begin{array}{l}
\underline{\mathrm{F}} \quad \mathrm{X} 100 \% \\
\mathrm{~N}
\end{array} \\
& \mathrm{P}=\text { persentase capaian } \\
& \mathrm{X}=\text { Skor perolehan } \\
& \mathrm{Y}=\text { Jumlah skor maksimal }
\end{aligned}
$$

\section{Prosedur Penelitian}

Prosedur penelitian adalah suatu rangkaian tahap-tahap penelitian dari awal sampai akhir. Penelitian ini merupakan proses pengkajian sistem berdaur atau bersiklus sebagaimana kerangka berpikir yang dikembangkan oleh Suharsimi Arikunto dkk. Prosedur ini mencakup tahap-tahap: (1) perencanaan, (2) pelaksanaan, (3) pengamatan, dan (4) refleksi.

\section{Analisis Data}

Di dalam melakukan analisis data peneliti mengacu kepada tahapan yang dijelaskan Miles dan Huberman yang terdiri dari tiga tahapan yaitu: reduksi data (data reduction), penyajian data (data display) dan penarikan kesimpulan atau verifikasi (conclusion drawing/verivication), biasa dikenal dengan model analisis interaktif (interactive model of analysis).

\section{HASIL DAN PEMBAHASAN}

\section{Hasil Penelitian}

Hasil wawancara terhadap dengan dua belas orang guru sebagai subyek penelitian di TK Al Mustafa Kota Jambi diperoleh informasi: (1) beberapa guru belum/tidak tahu kerangka penyusunan Rencana Pelaksanaan Pembelajaran (RPP); (2) hanya dua orang guru yang pernah mengikuti pelatihan pengembangan RPP; (3) umumnya guru mengadopsi dan mengadaptasi Rencana Pelaksanaan Pembelajaran (RPP); (4) kebanyakan guru tidak tahu dan tidak paham menyusun Rencana Pelaksanaan Pembelajaran (RPP) secara lengkap, mereka setuju bahwa

${ }^{4}$ Sudjana, Metode Statistika. (Bandung: PT Tarsito, 2005), hal. 31. 
guru harus menggunakan Rencana Pelaksanaan Pembelajaran (RPP) dalam melaksanakan proses pembelajaran yang dapat dijadikan acuan/pedoman dalam proses pembelajaran; dan (5 kebanyakan guru belum tahu dengan komponenkomponen Rencana Pelaksanaan Pembelajaran (RPP) secara lengkap.

Berdasarkan hasil observasi dan studi dokumentasi yang peneliti lakukan terhadap dua belas Rencana Pelaksanaan Pembelajaran (RPP) yang dibuat guru (khusus pada siklus I), diperoleh informasi/data bahwa masih ada guru yang tidak melengkapi RPP-nya dengan komponen dan sub-sub komponen Rencana Pelaksanaan Pembelajaran (RPP) tertentu, misalnya komponen indikator dan penilaian hasil belajar (pedoman penskoran dan kunci jawaban). Rumusan kegiatan siswa pada komponen langkah-langkah kegiatan pembelajaran masih kurang tajam, interaktif, inspiratif, menantang, dan sistematis.

Hasil penelitian diperoleh bahwa setelah guru mengikuti in-house training penyusunan Rencana Pelaksanaan Pembelajaran (RPP) maka dapat disimpulkan terjadi peningkatan dalam menyusun rencana pelaksanaan pembelajaran dari siklus ke siklus. Hal itu dapat dilihat pada lampiran rekapitulasi hasil penyusunan Rencana Pelaksanaan Pembelajaran (RPP) dari siklus ke siklus.

\section{- Siklus I (Pertama)}

Siklus pertama terdiri dari empat tahap yakni: (1) perencanaan, (2) pelaksanaan, (3) observasi, dan (4) refleksi seperti berikut ini.

a. Perencanaan (planning)

1) Membuat lembar wawancara

2) Membuat format/instrumen penilaian Rencana Pelaksanaan Pembelajaran (RPP).

3) Membuat format rekapitulasi hasil penyusunan Rencana Pelaksanaan Pembelajaran (RPP) siklus I dan II

4) Membuat format rekapitulasi hasil penyusunan Rencana Pelaksanaan Pembelajaran (RPP) dari siklus ke siklus

b. Pelaksanaan (Acting)

Pada saat awal siklus pertama indikator pencapaian hasil dari setiap komponen Rencana Pelaksanaan Pembelajaran (RPP) belum sesuai/tercapai 
seperti rencana/keinginan peneliti. Hal itu dibuktikan dengan masih adanya komponen Rencana Pelaksanaan Pembelajaran (RPP) yang belum dibuat oleh guru.

Hasil observasi pada siklus pertama dapat dideskripsikan berikut ini:

Observasi dilaksanakan pada 25 Oktober 2017, terhadap seluruh guru. Semuanya menyusun Rencana Pelaksanaan Pembelajaran (RPP), tapi masih ada guru yang belum melengkapi RPP-nya baik dengan komponen maupun sub-sub komponen Rencana Pelaksanaan Pembelajaran (RPP) tertentu. Tiga guru tidak melengkapi Rencana Pelaksanaan Pembelajaran (RPP)-nya dengan komponen indikator pencapaian kompetensi. Untuk komponen penilaian hasil belajar, dapat dikemukakan sebagai berikut.

1) Dua guru tidak melengkapinya dengan teknik dan bentuk instrumen.

2) Satu guru tidak melengkapinya dengan teknik, bentuk instumen, soal, pedoman penskoran, dan kunci jawaban.

3) Dua orang tidak melengkapinya dengan teknik, pedoman penskoran, dan kunci jawaban.

4) Satu orang tidak melengkapinya dengan soal, pedoman penskoran, dan kunci jawaban.

5) Satu guru tidak melengkapinya dengan pedoman penskoran dan kunci jawaban.

Secara lengkap, hasil penilaian terhadap penyusunan Rencana Pelaksanaan Pembelajaran (RPP) yang disusun guru setelah dilakukan pembinaan sebagai berikut:

TABEL 1: Persentase Penilaian Komponen Menyusun Rencana Pelaksanaan Pembelajaran (RPP) Siklus I

\begin{tabular}{|l|l|l|l|l|l|l|}
\hline No & \multicolumn{1}{|c|}{ Indikator } & Ada & $\%$ & $\begin{array}{l}\text { Tidak } \\
\text { ada }\end{array}$ & $\%$ & Keterangan \\
\hline 1 & Identitas & 9 & 75 & 3 & 25 & Baik \\
\hline 2 & Standar kompetensi & 10 & 83 & 2 & 17 & Baik \\
\hline
\end{tabular}




\begin{tabular}{|l|l|l|l|l|l|l|}
\hline 3 & Kompetensi dasar & 10 & 83 & 2 & 17 & Baik \\
\hline 4 & Indikator pembelajaran & 9 & 75 & 3 & 25 & Baik \\
\hline 5 & Tujuan pembelajaran & 8 & 67 & 4 & 33 & Kurang \\
\hline 6 & Materi pembelajaran & 8 & 67 & 4 & 33 & Kurang \\
\hline 7 & Alokasi waktu & 7 & 58 & 5 & 42 & Kurang \\
\hline 8 & Kegiatan proses & 11 & 92 & 1 & 8 & $\begin{array}{l}\text { Sangat } \\
\text { baik }\end{array}$ \\
\hline 9 & Pembelajaran & 12 & 100 & 0 & 0 & $\begin{array}{l}\text { Sangat } \\
\text { baik }\end{array}$ \\
\hline 10 & Sumber belajar & 9 & 75 & 3 & 25 & Baik \\
\hline 11 & Penilaian & 5 & 42 & 7 & 58 & Kurang \\
\hline & Rata-rata & & 74 & & 26 & Cukup \\
\hline
\end{tabular}

Persentase komponen penilaian Rencana Pelaksanaan Pembelajaran (RPP) di atas masih menunjukkan nilai rata-rata cukup (74\%). Di mana hampir semua aspek belum memenuhi kriteria penyusunan Rencana Pelaksanaan Pembelajaran (RPP) yang baik dan benar. Selanjutnya mereka dibimbing dengan mengikuti inhouse training dan disarankan untuk melengkapinya.

\section{- Siklus II (Kedua)}

Siklus kedua juga terdiri dari empat tahap yakni: (1) perencanaan, (2) pelaksanaan, (3) observasi, dan (4) refleksi. Hasil observasi pada siklus kedua dapat dideskripsikan berikut ini:

Observasi dilaksanakan pada tanggal 8 November 2017, terhadap seluruh guru. Semuanya menyusun Rencana Pelaksanaan Pembelajaran (RPP), tapi masih ada guru yang keliru dalam menentukan kegiatan siswa dalam langkah-langkah kegiatan pembelajaran dan metode pembelajaran, serta tidak memilah/menguraikan materi pembelajaran dalam sub-sub materi. Untuk komponen penilaian hasil belajar, dapat dikemukakan sebagai berikut.

a. Satu orang keliru dalam menentukan teknik dan bentuk instrumennya.

b. Satu orang keliru dalam menentukan bentuk instrumen berdasarkan teknik penilaian yang dipilih. 
c. Satu orang kurang jelas dalam menentukan pedoman penskoran. Secara lengkap, hasil penilaian terhadap penyusunan komponen Rencana Pelaksanaan Pembelajaran (RPP) yang disusun guru setelah dilakukan pembinaan pada siklus kedua didapat hasil sebagai berikut:

Tabel 2 Persentase Penilaian Komponen Menyusun Rencana Pelaksanaan Pembelajaran RPP Siklus II

\begin{tabular}{|l|l|l|l|l|l|l|}
\hline No & \multicolumn{1}{|c|}{ Indikator } & ada & $\%$ & $\begin{array}{l}\text { Tidak } \\
\text { ada }\end{array}$ & $\%$ & keterangan \\
\hline 1 & Identitas & 12 & 100 & 0 & 0 & Sangat baik \\
\hline 2 & Standar kompetensi & 10 & 83 & 2 & 17 & Baik \\
\hline 3 & Kompetensi dasar & 12 & 100 & 0 & 0 & Sangat Baik \\
\hline 4 & $\begin{array}{l}\text { Indikator } \\
\text { pembelajaran }\end{array}$ & 9 & 75 & 3 & 25 & Baik \\
\hline 5 & Tujuan pembelajaran & 9 & 75 & 3 & 25 & Baik \\
\hline 6 & Materi pembelajaran & 11 & 92 & 1 & 8 & Baik \\
\hline 7 & Alokasi waktu & 9 & 75 & 3 & 25 & baik \\
\hline 8 & Metode pembelajaran & 11 & 92 & 1 & 8 & baik \\
\hline 9 & $\begin{array}{l}\text { Kegiatan proses } \\
\text { Pembelajaran }\end{array}$ & 12 & 100 & 0 & 0 & Sangat baik \\
\hline 10 & Sumber belajar & 9 & 75 & 3 & 25 & Baik \\
\hline 11 & Penilaian & 9 & 75 & 3 & 25 & Baik \\
\hline & \multicolumn{2}{|c|}{ Rata-rata } & 86 & & 14 & baik \\
\hline
\end{tabular}

Persentase komponen penilaian Rencana Pelaksanaan Pembelajaran (RPP) di atas menunjukkan nilai rata-rata baik (86\%). Dimana hampir semua aspek memenuhi kriteria penyusunan Rencana Pelaksanaan Pembelajaran (RPP) yang baik dan benar. 


\section{Pembahasan}

Penelitian Tindakan Sekolah dilaksanakan di TK Al Mustafa Kota Jambi dan dilaksanakan dalam dua siklus. Kedua belas guru kelas tersebut menunjukkan sikap yang baik dan termotivasi dalam menyusun Rencana Pelaksanaan Pembelajaran (RPP) dengan lengkap. Hal ini peneliti ketahui dari hasil pengamatan pada saat melakukan wawancara dan in house training pembuatan RPP.

Selanjutnya dilihat dari kompetensi guru dalam menyusun Rencana Pelaksanaan Pembelajaran (RPP), terjadi peningkatan dari siklus ke siklus. Pada siklus pertama sembilan guru mencantumkan identitas mata pelajaran dalam RPPnya (melengkapi RPP-nya dengan identitas mata pelajaran). Jika dipersentasekan, 75\%. Tiga orang guru mendapat skor 0 (tidak mencantumkan) dan 9 orang mendapat skor 2 (mencantumkan). Pada siklus kedua semua guru tersebut mencantumkan identitas mata pelajaran dalam Rencana Pelaksanaan Pembelajaran (RPP)-nya. Semuanya mendapat skor 2 (mencantumkan). Jika dipersentasekan, $100 \%$, terjadi peningkatan $25 \%$ dari siklus I.

Pada siklus pertama sepuluh guru mencantumkan standar kompetensi dalam Rencana Pelaksanaan Pembelajaran (RPP)-nya (melengkapi RPP-nya dengan standar kompetensi). Jika dipersentasekan, 70\%. Masing-masing 2 orang guru mendapat skor 0 dan 1orang mendapat skor 1 (tidak ada dan tidak sempurna). Sembilan orang guru mendapat skor 2 (lengkap). Pada siklus kedua sepuluh guru mencantumkan standar kompetensi dalam Rencana Pelaksanaan Pembelajaran (RPP)-nya. Dua orang mendapat skor 0 (tidak ada). Jika dipersentasekan, 92\%, terjadi peningkatan dari siklus I sebanyak $32 \%$.

Pada siklus pertama sepuluh guru mencantumkan kompetensi dasar dalam Rencana Pelaksanaan Pembelajaran (RPP)-nya (melengkapi RPP-nya dengan kompetensi dasar). Jika dipersentasekan, 79\%. Satu orang guru masing-masing mendapat skor 1 (tidak lengkap), delapan orang guru mendapat skor 2 (sangat baik) dan 2 orang mendapat skor 0 (tidak ada). Pada siklus kedua semua guru tersebut mencantumkan kompetensi dasar dalam RPP-nya. Jika dipersentasekan, $100 \%$, terjadi peningkatan $21 \%$ dari siklus I. 
Pada siklus pertama sembilan orang guru mencantumkan indikator pencapaian kompetensi dalam Rencana Pelaksanaan Pembelajaran (RPP)-nya (melengkapi Rencana Pelaksanaan Pembelajaran (RPP)-nya dengan indikator pencapaian kompetensi). Sedangkan tiga orang tidak mencantumkan/melengkapinya. Jika dipersentasekan, 75\%. Tiga orang guru mendapat skor 0 (tidak ada). Sembilan orang guru mendapat skor 2 (lengkap). Pada siklus II tidak terjadi peningkatan dari siklus I hanya terjadi kesalahan pada guru yang berbeda.

Pada siklus pertama delapan guru mencantumkan tujuan pembelajaran dalam RPPnya (melengkapi RPP-nya dengan tujuan pembelajaran). Jika dipersentasekan, 67\%. Empat orang guru mendapat skor 0 (tidak ada), Pada siklus kedua sembilan guru mencantumkan tujuan pembelajaran dalam Rencana Pelaksanaan Pembelajaran (RPP)-nya. dan tiga orang mendapat skor 0 (tidak ada). Jika dipersentasikan,75\% terjadi peningkatan $8 \%$ dari siklus I.

Pada siklus pertama delapan guru mencantumkan materi ajar dalam RPPnya (melengkapi RPP-nya dengan materi ajar). Jika dipersentasekan, 67\%. Empat orang guru mendapat skor 0 (tidak ada). Pada siklus kedua sebelas guru mencantumkan materi ajar dalam Rencana Pelaksanaan Pembelajaran (RPP)-nya. Hanya satu orang mendapat 0 (tidak ada). Jika dipersentasekan, 92\%, terjadi peningkatan $25 \%$ dari siklus I.

Pada siklus pertama tujuh guru mencantumkan alokasi waktu dalam RPPnya (melengkapi RPP-nya dengan alokasi waktu). Semuanya mendapat skor 2 (baik). Jika dipersentasekan, 58\%. Pada siklus kedua sepuluh guru tersebut mencantumkan alokasi waktu dalam Rencana Pelaksanaan Pembelajaran (RPP)nya. Jika dipersentasekan, $83 \%$, terjadi peningkatan $25 \%$ dari siklus I. Pada umumnya guru lupa mencantumkan alokasi waktu pada Rencana Pelaksanaan Pembelajaran (RPP) mereka.

Pada siklus pertama sebelas guru mencantumkan metode pembelajaran dalam Rencana Pelaksanaan Pembelajaran (RPP)-nya (melengkapi RPP-nya dengan metode pembelajaran). Jika dipersentasekan, 88\%. Satu orang guru mendapat skor 0 (tidak ada), satu orang mendapat skor 1 (tidak lengkap). Pada 
siklus kedua sebelas guru tersebut mencantumkan metode pembelajaran dalam Rencana Pelaksanaan Pembelajaran (RPP)-nya. Satu orang mendapat skor 0 (tidak ada). Jika dipersentasekan, 92\%,terjadi peningkatan sebesar 4\% dari siklus I.

Pada siklus pertama semua guru mencantumkan langkah-langkah kegiatan pembelajaran dalam Rencana Pelaksanaan Pembelajaran (RPP)-nya (melengkapi RPP-nya dengan langkah-langkah kegiatan pembelajaran). Hanya 1 orang yang mendapat skor 1 (tidak lengkap). Jika dipersentasekan, 96\%. Pada siklus kedua semua guru tersebut mencantumkan langkah-langkah kegiatan pembelajaran dalam RPP-nya. Jika dipersentasekan, 100\%, terjadi peningkatan dari siklus I sebesar $4 \%$.

Pada siklus pertama sembilan guru mencantumkan sumber belajar dalam Rencana Pelaksanaan Pembelajaran (RPP)-nya (melengkapi RPP-nya dengan sumber belajar) hanya tidak sesuai ketentuan. Jika dipersentasekan hanya, 50\%. Tiga orang guru mendapat skor 0 (tidak ada), sedangkan enam orang mendapat skor 1 (tidak lengkap). Pada siklus kedua sembilan guru tersebut mencantumkan sumber belajar dalam Rencana Pelaksanaan Pembelajaran (RPP)-nya. Tiga orang mendapat skor 0 (tidak ada) dan empat orang mendapat skor 1 (tidak lengkap). Jika dipersentasekan, 58\%, terjadi peningkatan dari siklus I sebesar 8\%.

Pada siklus pertama lima guru mencantumkan penilaian hasil belajar dalam Rencana Pelaksanaan Pembelajaran (RPP) nya meskipun sub-sub komponennya (teknik, bentuk instrumen, soal), pedoman penskoran, dan kunci jawabannya kurang lengkap. Jika dipersentasekan, 29\%. tiga orang guru masing-masing mendapat skor 1 (tidak lengkap), dua orang mendapat skor 2 (lengkap), dan tujuh orang mendapat skor 0 (tidak ada). Pada siklus kedua sembilan guru mencantumkan penilaian hasil belajar dalam Rencana Pelaksanaan Pembelajaran (RPP)-nya meskipun ada guru yang masih keliru dalam menentukan teknik dan bentuk penilaiannya. Enam mendapat skor 2 (lengkap) dan tiga orang mendapat skor 1 (tidak lengkap) dan masih ada tiga orang guru yang tidak mencantumkan. Jika dipersentasekan, 54\%, terjadi peningkatan 25\% dari siklus I.

Berdasarkan pembahasan di atas terjadi peningkatan kompetensi guru TK Al Mustafa Kota Jambi dalam menyusun Rencana Pelaksanaan Pembelajaran 
(RPP). Pada siklus I nilai rata-rata komponen Rencana Pelaksanaan Pembelajaran (RPP) 74\%,pada siklus II nilai rata-rata komponen Rencana Pelaksanaan Pembelajaran (RPP) 86\%, terjadi peningkatan 12\%. Untuk mengetahui lebih jelas peningkatan setiap komponen Rencana Pelaksanaan Pembelajaran (RPP), dapat dilihat pada lampiran rekapitulasi hasil penyusunan Rencana Pelaksanaan Pembelajaran (RPP) dari siklus ke siklus.

\section{E. KESIMPULAN}

Berdasarkan hasil penelitian tindakan sekolah (PTS) dapat disimpulkan sebagai berikut. In house training mampu meningkatkan kompetensi guru TK Al Mustafa Kota Jambi dalam menyusun Rencana Pelaksanaan Pembelajaran (RPP). Hal itu dapat dibuktikan dari hasil observasi yang memperlihatkan bahwa terjadi peningkatan kompetensi guru dalam menyusun Rencana Pelaksanaan Pembelajaran (RPP) dari siklus ke siklus. Pada siklus I nilai rata-rata komponen Rencana Pelaksanaan Pembelajaran (RPP) 74\% dan pada siklus II 86\%. Jadi, terjadi peningkatan $12 \%$ dari siklus I.

Pendampingan yang dilakukan pengawas dengan melakukan kegiatan in House Trainng terhadap guru mampu meningkatkan kompetensi guru dalam menyusun rencana pelaksanaan pembelajaran (RPP). Jadi, pengawas dan kepala sekolah perlu secara kontinu melakukan pendampingan dan pembinaan kepada guru agar kemampuan guru dapat terus meningkat.

In house training dapat meningkatkan motivasi dan kompetensi guru dalam menyusun Rencana Pelaksanaan Pembelajaran (RPP). Oleh karena itu, peneliti menyampaikan beberapa saran sebagai berikut:

1. Motivasi yang sudah tertanam khususnya dalam penyusunan rencana pelaksanaan pembelajaran (RPP) hendaknya terus dipertahankan dan ditingkatkan/dikembangkan.

2. Rencana Pelaksanaan Pembelajaran (RPP) yang disusun/dibuat hendaknya mengandung komponen-komponen Rencana Pelaksanaan Pembelajaran (RPP) secara lengkap dan baik karena Rencana Pelaksanaan Pembelajaran (RPP) merupakan acuan/pedoman dalam melaksanakan pembelajaran 


\section{DAFTAR PUSTAKA}

Baharuddin, Manajemen Pendidikan Islam, Malang: UIN Maliki Press, 2010.

E. Mulyasa, Standar Kompetensi dan Sertifikasi Guru, Bandung: PT remaja Rosda karya, 2011.

E. Mulyasa, Kurikulum Tingkat Satuan Pendidikan, Bandung: PT. Remaja Rosdakarya, 2007.

E. Mulyasa, Implementasi KTSP, Kemandirian Guru dan Kepala Sekolah, Jakarta: Bumi Aksara, 2008.

Kunandar, Guru Profesional Implementasi KTSP dan Persiapan Menghadapi Sertifikasi Guru, Jakarta: Rajagrafindo Persada, 2007.

Nawawi, Hadari. 1985. Metode Penelitian Bidang Sosial. Yogyakarta: Gadjah Mada University Press 1985.

Oemar Hamalik, Pendidikan Guru Berdasarkan Pendekatan Kompetensi, Jakarta: Bumi Akasara , 2006.

Rahmat Raharjo, Inovasi Kurikulum Pendidikan Agama Islam, Pengembangan Kurikulum dan Pembelajaran, Yogyakarta: Magnum Pustaka, 2010.

Suharto dkk, Kamus Bahasa Indonesia Terbaru, Surabaya: Indah, 1996.

Sugiyono. Metode Penelitian Bisnis. Alfabeta : Bandung. 2008: 336

Sudjana. Metode Statistika. Bandung: PT Tarsito, 2005.

UU RI No. 14 Th. 2005, Guru dan Dosen, Jakarta: Sinar Grafika, 2006. 